\title{
Self-regulated learning, self-determination theory and teacher candidates' development of competency-based teaching practices
}

\author{
Charlotte Ann Brenner ${ }^{1,2^{*}}$ (1)
}

\section{*Correspondence:}

cb21289@gmail.com

${ }^{1}$ University of British

Columbia, Scarfe Building, Main Mall, Vancouver, BC V6T

1Z4, Canada

Full list of author information

is available at the end of the

article

\begin{abstract}
Self-regulated promoting practices foster students' development of metacognition, motivation and strategic action. These underlying learning competencies improve students' academic, social, emotional and career outcomes. Although beneficial, the development of self-regulated promoting practices is challenging, particularly for teacher candidates. This article describes self-regulated learning practices and how motivational supports for teacher candidates' self-determined motivation creates contextual conditions that foster teacher candidates' development of these practices. The article concludes with suggestions for future research.
\end{abstract}

Keywords: Self-regulated learning, Self-determination, Motivation, Teacher candidates, Teacher education programs, Competency-based teaching practices

\section{Introduction}

Developed nations value educational initiatives and innovations that support the promotion of flexible learning competencies that can be applied to diverse contexts (e.g., creative and critical thinking skills, communication skills, problem-solving skills, social responsibility and personal awareness; OECD, 2012; Perry et al., 2017). While beneficial, the development of teaching practices that foster these competencies is a complex. Drawing from self-regulated learning (SRL) theory (Zimmerman, 1990, 2008) and selfdetermination theory (SDT, Ryan \& Deci, 2017) this article presents a framework for supporting teacher candidates (TCs) to learn about and implement teaching practices aligned with students' development of flexible learning competencies.

\section{Self-regulated learning theory}

SRL theory attends to the development of three learning processes: metacognition, motivation, and strategic action (Winne \& Perry, 2000; Zimmerman, 2008). Metacognitive learners are aware of their personal learning strengths and challenges. They have knowledge of learning strategies and are attuned to others' needs and interests. Motivated learners are willing to attempt challenging tasks. They are persistent and believe that, with effort, they will succeed within learning tasks. Finally, strategic learners have

(c) The Author(s) 2022. Open Access This article is licensed under a Creative Commons Attribution 4.0 International License, which permits use, sharing, adaptation, distribution and reproduction in any medium or format, as long as you give appropriate credit to the original author(s) and the source, provide a link to the Creative Commons licence, and indicate if changes were made. The images or other third party material in this article are included in the article's Creative Commons licence, unless indicated otherwise in a credit line to the material. If material is not included in the article's Creative Commons licence and your intended use is not permitted by statutory regulation or exceeds the permitted use, you will need to obtain permission directly from the copyright holder. To view a copy of this licence, visit http:// creativecommons.org/licenses/by/4.0/. 
large repertoires of learning strategies. They are adaptive and flexible in their use of strategies and able to adjust strategies to meet the needs of various tasks.

Most models of SRL describe cyclical processes learners use to guide their thoughts and actions before, during, and after engaging in learning tasks (See: Butler \& Cartier, 2004; Winne \& Hadwin, 1998; Zimmerman, 2002). Zimmerman's SRL model identifies three phases of SRL: the forethought phase, during which learners set goals for themselves, assess their motivation and abilities to complete the tasks, and make plans for engaging in the task; the performance phase, when learners focus their attention, engage in tasks, develop and apply strategies, and monitor their progress, and the self-reflection phase, when learners reflect upon the task and their performance through self-evaluation. Butler and Cartier's (2018) model of SRL includes a sociocultural lens that links historical, cultural, social, and community contexts to it. While differing in scope, all SRL models emphasize the importance of iterative cycles of planning (forethought), enacting, reflecting, and adjusting thoughts and actions to achieve learning goals.

Aligned with Vygotskian theory (1978), self-regulation encompasses personal and social forms of learning. The cognitive and metacognitive processes of self-regulation are modeled and internalized through social interactions; this co-regulation with others fosters SRL in learners (McCaslin, 2009). Socially shared regulation expands upon the notion of co-regulation, referring to the regulation of common learning objectives shared within groups to achieve agreed upon goals (Hadwin et al., 2018).

Within groups (e.g., classroom settings), individuals engage in self-, co-, shared, and socially responsible forms of regulation. Individuals plan, monitor, and evaluate their contributions to the group (i.e., self-regulation), while members within the group provide modelling of cognitive and metacognitive strategies, as well as motivational support (i.e., co-regulation; Hadwin et al., 2018; Hutchinson, 2013). Together the group might plan, implement, and evaluate their collective actions (i.e., socially-shared regulation). It is within this collaboration that socially responsible self-regulation is fostered.

\section{Why is supporting SRL important?}

SRL pairs well with current educational initiatives and innovations $\left(21^{\text {st }}\right.$-century learning, inquiry learning, inclusion, assessment for learning). SRL is linked to students becoming adaptive, lifelong learners who are critical and creative thinkers, problem solvers, and able to work and learn both independently and collaboratively (Perry et al., 2017). The development of SRL is a significant source of achievement differences among students (Zimmerman \& Schunk, 2011). Furthermore, it is an asset that cuts across socio-demographic boundaries (McClelland \& Wanless, 2012; Perry et al., 2017). Selfregulation is developmental: all learners can improve capacities for self-regulating, including those with exceptional learning needs, and use these capacities to support their learning (Stoeger et al., 2015; Wong et al., 2003).

\section{What does SRL look like in classrooms?}

Perry and colleagues (Perry, 1998, 2013; Perry et al., 2018) have identified a set of selfregulated learning promoting practices (SRLPPs) that teachers implement to create opportunities for students to engage in SRL. These practices (shown in Table 1) support students' metacognition, motivation, and cycles of strategic action, often in the 
Table 1 Classroom practices that support self-regulated learning

\begin{tabular}{|c|c|}
\hline Practices & Description \\
\hline Choice & $\begin{array}{l}\text { Students are involved in choices that involve higher level decision making (e.g., topics } \\
\text { to research, what resources to use; how to organize information; roles for collaborative } \\
\text { group members; time management; working conditions, partners) }\end{array}$ \\
\hline Control over challenge & $\begin{array}{l}\text { Students are given opportunities to negotiate with their teacher or independently } \\
\text { make modifications/adaptations to learning tasks based on their learning needs and } \\
\text { interests (e.g., students work at their own pace; decide on the length of writing assign- } \\
\text { ments; determine presentation formats) }\end{array}$ \\
\hline Self-assessment & $\begin{array}{l}\text { Students self-evaluate their work. They are aware of criteria for tasks and have oppor- } \\
\text { tunities to assess their on-going progress (e.g., to consider their work in relation to task } \\
\text { criteria and their own learning goals) }\end{array}$ \\
\hline Teacher support & $\begin{array}{l}\text { Teachers provide students with support that is instrumental to their self-regulated } \\
\text { learning. They guide students toward independence by supporting their development } \\
\text { of skills to solve problems for themselves (e.g., rather than telling a student how to } \\
\text { complete a task, the teacher promotes metacognitive thought through questioning } \\
\text { [e.g., "Can you think ...;;"What strategies could you use..."]). Teachers support student } \\
\text { motivation by using motivational language that emphasizes the role of effort, effective } \\
\text { strategy use, and personal growth over external indicators of performance (e.g., grades) }\end{array}$ \\
\hline Support from peers & $\begin{array}{l}\text { Similar to teacher support, peers provide instrumental support, they offer growth ori- } \\
\text { ented motivational messages (as described above). Additionally, discussions with peers } \\
\text { about learning, supports students'awareness and understanding of learning and their } \\
\text { needs/strengths as learners }\end{array}$ \\
\hline Embedded assessment & $\begin{array}{l}\text { Teachers provide students with feedback (verbal, visual or written). Teachers keep } \\
\text { records regarding student progress and continually reflect on how students are } \\
\text { responding to tasks and teaching strategies }\end{array}$ \\
\hline Complex tasks & $\begin{array}{l}\text { Teachers engage students in complex tasks. Often, these tasks address multiple goals. } \\
\text { They incorporate content goals; goals for the development of cognitive and metacogni- } \\
\text { tive processes (e.g., students are asked to select and evaluate strategies). Complex tasks } \\
\text { scaffold student learning (e.g., they teach skills and concepts in a manner that builds } \\
\text { upon students current skills and processes). These tasks are meaningful to students and } \\
\text { integrate content and skills from across the curriculum. Complex tasks also allow for } \\
\text { multiple representations of learning. Students may represent learning in an oral presen- } \\
\text { tation, through a written report, a multi-dimensional model or other visual display) }\end{array}$ \\
\hline $\begin{array}{l}\text { Accommodation for } \\
\text { individual differences }\end{array}$ & $\begin{array}{l}\text { Tasks, activities, models of assessment are open and flexible. They accommodate differ- } \\
\text { ences in abilities and allow for the participation of all students. To this end, adaptions } \\
\text { in criteria for assessment are made, or can be made, to accommodate individual differ- } \\
\text { ences. Additionally, tasks are universally designed to enable meaningful participation of } \\
\text { all students. Tasks that address multiple learning goals and fit learners' needs support all } \\
\text { areas of SRL }\end{array}$ \\
\hline
\end{tabular}

Adapted from Perry, 1998, 2013

context of complex tasks that require creative and/or critical thinking and problem solving. These practices provide a roadmap for TCs' to begin to foster SRL within their practicum classrooms.

Teachers use multiple strategies to facilitate the development of metacognition, motivation, and strategic action. For example, teachers support students' metacognition when they: make learning visible and provide opportunities for students to gather knowledge about themselves as learners through self-assessment and reflection; provide visual prompts; engage students in group discussions and encouraged task interpretation through metacognitive questioning (e.g., What strategy could help solve this?: Perry, 2013). Students' motivation is supported when: students are provided with choice (e.g., in learning goals and working conditions), opportunities for social interactions, and support to engage in meaningful, optimally challenging tasks (Perry). Strategic action develops as students engage in iterative cycles of planning, enacting, monitoring, and adjusting (Butler \& Cartier, 2004, 2018). Throughout this 
process, students consider the utility of multiple strategies to guide their productive engagement in learning tasks.

Strategic action is also fostered before, during, and after students' engagement in tasks. For example, prior to tasks, teachers and/or peers can provide support for learning through instruction, resources, and information. These forms of instrumental support help students to develop, apply, and revise strategies to meet their learning needs throughout their engagement in tasks (Butler \& Cartier, 2004, 2018).

While SRLPPs are effective, their development is difficult. Supporting SRL requires sophisticated awareness of and responsiveness to students' needs, and the understanding and use of complex teaching strategies (Brown \& Campione, 1994). Ideally, teachers target students' "zones of proximal development" (Vygotsky, 1978), providing "just enough" and "just in time" support, thereby allowing students solve problems independently (Perry \& Rahim, 2011). These teaching practices are likely particularly challenging for TCs who are often focused on the procedural and curricular demands of teaching and their own "survival needs" (Fuller \& Bown, 1975; Perry et al., 2006; Whitaker, 2000). However, while challenging, TCs can successfully develop SRLPPs if they are given explicit instruction and intensive scaffolding for doing so (Perry et al., 2006).

\section{Supporting TCs' development of SRLPPs through self-determination theory}

SDT offers a lens through which to view TCs' personal characteristics and contextual features that might be implicated in their understanding and development of SRLPPs. SDT assumes that people are driven towards growth, specifically the desire to contribute and connect to society, and to master challenges in their environments (Ryan \& Deci, 2017). According to SDT, this innate drive towards positive growth is where cultural values and behaviours are learned, assimilated, and maintained (Sheldon \& Ryan, 2011).

Across cultures, motivation to engage in social practices is nurtured by the satisfaction of three basic psychological needs, autonomy, competence, and relatedness (Deci \& Ryan, 2014). Autonomy is a person's sense of volition to act, to be open to the influence of others, and yet maintain a sense of choice and freedom about their thoughts and actions (Ryan \& Deci, 2017). Competence is people's perceived experiences of being able to influence and master tasks within their environments (Evelein et al., 2008; Ryan \& Deci, 2017; White, 1959). Relatedness is the perception of being able to connect with others and maintain trusting, respectful relationships (Reeve \& Assor, 2011; Ryan \& Deci, 2002, 2017). Collectively these needs are referred to as self-determination needs (SD needs; Sheldon \& Ryan 2011; Ryan \& Deci, 2017). The fulfillment of SD needs is associated with positive outcomes including increased adaptability, task engagement, vitality, self-confidence, and well-being (Reeve \& Jang, 2006; Ryan, 1995; Ryan \& Deci, 2017) - all of which facilitate people's ongoing growth and engagement in their surroundings. Conversely, conditions that thwart the fulfillment of these needs hinder personal growth (Howard et al., 2017; Jang et al., 2016; Reeve, 2015; Ryan, 1995). Unmet SD needs result in increased negative emotions, behaviours focused on self-protection, and decreased cognitive flexibility and self-determined motivation, all of which are associated with maladaptive functioning and stagnation in personal growth (Baard, 1994; Evelein et al., 2008; Ryan \& Deci, 2017; Sheldon \& Ryan 2011). 


\section{Causality orientations and contexts}

In SDT, motivational (causality) orientations describe the forms of regulation people are likely to use and the extent to which they seek features in their environments that are supportive of autonomous, controlled, and amotivated forms of motivation (Deci \& Ryan, 2008). People hold all three motivational orientations (autonomous, controlled, and impersonal) to some degree, however, one form of motivation is generally dominant in learning contexts (Deci \& Ryan, 2012). SDT posits that motivational orientations are formed through dialectic interactions between people and the contexts in which they function over time (Reeve et al., 2018). People's perceptions and orientation to supports for their motivation in their environments are shaped by their motivational orientations (Vallerand \& Ratelle, 2002), which in turn are determined by the extent that they have been exposed to environments supportive of their motivational needs (Gagné \& Deci, 2005; Reeve et al., 2003, 2018).

The motivational orientations people hold influence their engagement in activities, emotional well-being, and performance. In comparison to those with controlled motivational orientations, people with autonomous motivational orientations demonstrate higher levels of self-regulation, engagement, perceived competence, relatedness with peers and authority figures, cognitive flexibility, performance, and well-being (Baard et al., 2004; Black \& Deci, 2000; Deci \& Ryan, 1985, 2008; Reeve et al., 2018; Williams \& Deci, 1996). In turn, those with controlled motivational orientations report higher levels of self-consciousness, power seeking, competitive behaviours, anxiety, depression, and self-degradation (Deci \& Ryan, 1985, 2008). People with impersonal orientations are prone to apathy, withdrawal, and a tendency towards maladaptive environmental influences, all of which promote feelings of incompetence (Deci \& Ryan, 1985, 1991).

\section{Contextual supports for motivation}

Autonomy-supportive environments facilitate the fulfillment of all three psychological needs by providing choice, informational support, meaningful rationales, models for socially desired behaviours, and opportunities for self-initiated behaviour (Deci et al., 1994; Gagné \& Deci, 2005; Reeve et al., 2018; Vansteenkiste et al., 2006). Autonomysupportive environments create space for people to: (a) form personal beliefs about the value of tasks, (b) increase their feelings of competence, and (c) collaborate with others, all of which facilitate engagement and autonomous motivation (Baard et al., 2004; Gagné \& Deci, 2005; Reeve et al., 2018; Ryan \& Deci, 2017).

In contrast, controlling environments hinder engagement and the development of autonomous forms of regulation. These environments limit choice and information; they shape behaviours through the use of rewards and punishments (Black \& Deci, 2000). Such conditions serve to undermine personal valuing of tasks, thereby fostering a reliance on external conditions and forms of regulation to elicit, maintain, and promote task engagement (Black \& Deci, 2000; Reeve et al., 2018).

\section{Self-determination theory in the domain of teaching}

Research indicates contextual supports for TCs' and teachers' self-determined motivation increases the likelihood they will use instructional practices known to support 
students' self-determined motivation and learning (Korthagen \& Evelein, 2016; Liu et al., 2019; Pelletier et al., 2002; Niemiec \& Ryan, 2009; Reeve, 2009, 2015). Not surprisingly, given the overlap in foci across SRL theory and SDT (e.g., developing selfor autonomous regulation), many of the instructional practices associated with SRL are also cited in self-determination literature (see: Baard et al., 2004; Deci et al., 1994; Deci \& Ryan, 2000; Gagné \& Deci, 2005; Lee \& Reeve, 2017; Niemiec \& Ryan, 2009; Pelletier et al., 2002; Perry, 1998, 2013; Perry et al., 2002; Reeve, 2009, 2015; Reeve et al., 2018; Vansteenkiste et al., 2006; Zimmerman \& Schunk, 2011). Table 2 below summarizes common instructional strategies found across SDT and SRL literature.

Multiple studies link SD instructional practices to positive student outcomes (See: Black \& Deci, 2000; Pelletier et al., 2002; Jang, 2009; Jang et al., 2010; Levesque et al. 2004; Niemiec \& Ryan, 2009; Reeve et al., 1999; Roth et al., 2007). A summary of this research indicates that when students' SD motivation is supported, they are more likely to value tasks, perceive an internal locus of causality, and self-regulate their behaviour. Additionally, teachers' provision of autonomy-supportive environments is linked to higher levels of student well-being (Sheldon \& Krieger, 2007; Cheon et al., 2014), self-esteem (Deci et al., 1981) and task engagement (Cheon et al., 2014). In these ways, student effort, persistence, and performance are supported both from internal and external sources.

- As in the case of students, teacher are more willing to attempt and engage in new and challenging activities if their motivational needs are supported. When teachers' selfdetermined motivation is thwarted by the presence of external forms of control (e.g., rigid directives for practices), their willingness to consider new educational practices declines (Ryan \& Brown, 2005; Ryan \& Weinstein, 2009). It is therefore likely that "top down" models of professional development, intended to support ongoing growth, may make teachers resistant to exploring new practices over time (Butler et al., 2014). As described below, these findings have important implications for TCs' development of SRLPPs.

Table 2 Instructional practices that support learners'SRL and self-determined motivation

\begin{tabular}{|c|c|c|}
\hline SD needs & $\begin{array}{l}\text { Instructional practices that support SD } \\
\text { motivation }\end{array}$ & Instructional practices that promote SRL \\
\hline Autonomy & $\begin{array}{l}\text { Minimize directives } \\
\text { Communicate flexible expectations } \\
\text { Provide choice } \\
\text { Provide rationales for tasks }\end{array}$ & $\begin{array}{l}\text { Provide opportunities for students to take } \\
\text { control of learning } \\
\text { Individualize expectations } \\
\text { Provide choice } \\
\text { Give students opportunities to select } \\
\text { meaningful tasks }\end{array}$ \\
\hline Competence & $\begin{array}{l}\text { Encourage student involvement } \\
\text { Provide appropriately challenging activities } \\
\text { Provide ongoing scaffolding support for task } \\
\text { engagement } \\
\text { Provide informative feedback }\end{array}$ & $\begin{array}{l}\text { Establish familiar routines } \\
\text { Structure supports for participation } \\
\text { Provide appropriately challenging activities } \\
\text { Provide ongoing scaffolding for SRL } \\
\text { Provide informative feedback }\end{array}$ \\
\hline Relatedness & $\begin{array}{l}\text { Respond to students' needs and interests } \\
\text { Sustain positive teacher and student interactions }\end{array}$ & $\begin{array}{l}\text { Respond to students' current interests and } \\
\text { abilities } \\
\text { Provide individualized instruction } \\
\text { Offer teacher encouragement and oppor- } \\
\text { tunities for student collaboration }\end{array}$ \\
\hline
\end{tabular}




\section{Contextual supports for TCs' motivational needs}

To date, research examining links between the development and implementation of teaching practices and the fulfilment of SD needs has been primarily focused on teachers. Below, I draw from available research (conducted with teachers and TCs) to illustrate how the fulfilment of SD needs likely facilitates TCs' development of SRLPPs within school settings.

\section{Relatedness}

Characterize by quality relationships; a strong sense of relatedness leads to increased perceptions of attachment and well-being at the individual level (Reeve et al., 2018). Conversely, when the need for relatedness is unfulfilled, negative reactions occur including withdrawal and decreased feelings of well-being (Skinner \& Edge, 2002). In most organizational settings, employees identify relationships with colleagues as facilitating their need for relatedness. For teachers, their sense of relatedness is also dependent upon the quality of connections they have with students (Evelein et al., 2008; Klassen et al., 2012). Teachers who report high levels of relatedness with students are more likely to experience positive teacher outcomes (as measured by emotional well-being, exhaustion, engagement, and perceived competence) in comparison to teachers whose main connections were with their colleagues (Klassen et al., 2012)

The establishment of positive connections with students impacts TCs' development of teaching and communication practices throughout their practicum experiences (Brenner, 2020; Perry et al. 2012) TCs who report positive connections with students experience more frequent affirmative interactions with students (Evelein et al., 2008). These interactions, in turn, increase the likelihood of TCs demonstrating behaviours that sustain constructive teacher-student exchanges leading to positive emotional learning climates (Evelein). Such relationships are also likely related to a reduction in students' disruptive behaviour; however, the direction of this relationship is unknown (Evelein).

TCs also value relationships with their TC peers, mentor teachers and university advisors (Brenner, 2020; Perry et al. 2012). Brenner (2020), found TCs' relationships with these individuals provide TCs with support for their sense of relatedness, developing competence and emerging autonomy. Therefore, supportive peers, mentors and advisors can be central forces in TCs' development of SRLPPs.

\section{Autonomy}

Perceptions of autonomy support authenticity. Feeling autonomous increases people's sense of freedom to implement practices in a way that is congruent with their own values, beliefs, and sense of self. When perceived autonomy is thwarted, people are likely to feel threatened, become defensive and disengagement from activities as a means of selfprotection (Skinner \& Edge, 2002).

For TCs, supports for autonomy are especially relevant. In order to authentically accommodate new knowledge into their practice, TCs' need the freedom and space to explore how practices align with their existing values, beliefs and practices about teaching. If TCs are placed in environments that lack supports for their autonomy, their focus may be on self-protection rather than on developing and implementing new knowledge 
and practices (Brenner, 2020). In this way, the provision of contextual supports for TCs' autonomy can impact TCs' development of teaching practices (e.g. SRLPPs).

Links between teachers' perceived experiences of autonomy and their use of instructional strategies and practices are well documented. A summary of the findings from these studies indicates that when teachers' autonomy needs are fulfilled, they are more likely to: (a) experience higher levels of self-determined motivation, (b) provide students with meaningful rationales for tasks, (c) minimize controlling forms of classroom management and instruction, (d) encourage student input, (e) create opportunities for students to make choices and decisions, and (f) provide instrumental support-which, combined, provide support for students' SRL and SD motivational needs (Carson \& Chase, 2009; Deci \& Ryan, 2002; Lam et al., 2010; Marshik, 2010; Pelletier et al., 2002; Reeve, 2002; Reeve \& Jang, 2006; Roth et al., 2007; Ryan \& Brown, 2005; Taylor et al., 2008) This evidence, drawn from teacher populations suggests that the provision of support for autonomy encourages TCs to attempt practices supportive of students' selfdetermined motivation and SRL.

\section{Competence}

School level influences appear to have the greatest impact upon teachers' perceived sense of competence. When administrators ensure reasonable workloads and coordinate opportunities for staff development, their needs for competence are supported (Lam et al., 2010). Teachers' perceived competence and self-determined motivation are also positively influenced through constructive informational feedback from administrators, mentors, colleagues, and students (Elliot et al., 2002). Feedback provides teachers with ongoing guidance, allowing them to better implement and refine their practice over time (Elliot et al., 2002; Pelletier \& Sharp, 2009; Tschannen-Moran \& Woolfolk-Hoy, 2007).

Higher levels of teacher efficacy increases the likelihood that teachers will engage in, and persist with, challenging, effective teaching practices (Jesus \& Lens, 2005; Schellenbach-Zell \& Cornelia, 2010). When teachers feel efficacious, they use fewer controlling classroom management techniques, encourage student autonomy during problem solving tasks, provide appropriately challenging activities, and persist in supporting students with learning challenges (Podell \& Soodak, 1993; Woolfolk et al., 1990). Viewing this research from an SDT perspective, teachers with high self-efficacy (i.e., teachers who have high levels of perceived competence for teaching tasks) are more apt to use student-centered forms of classroom management (supporting autonomy and relatedness with students), provide student choice during tasks (supporting autonomy), scaffold student learning, and offer students instrumental support (supporting competence).

In the case of TCs, research indicates that reasonable workloads, constructive feedback, and supervisory guidance in planning and designing lessons are of particular importance in raising TCs' perceived levels of competence (Carson \& Chase, 2009; Evelein et al., 2008). Moreover, TCs' espoused beliefs about the value of the utility of SRLPPs also appear to be associated with feelings of competence. Brenner, 2020; Perry et al. 2012 findings indicated that when TCs perceive SRLPPs to be useful (i.e., they believe SRLPPs help them perform teaching tasks that are important to them, such as managing problem behaviour and accommodating diverse learning needs in their classrooms), they perceive higher levels of competence. 


\section{TCs' motivational orientations, contexts and instructional practices}

Motivational orientations and contextual features appear to act together to shape teachers' perceptions of self-determination and use of professional practices (Brenner, 2020; Perry et al. 2012; Reeve et al. 1999; Reeve et al., 2018; Taylor et al., 2008). TCs with autonomous motivational orientations are more likely to listen and respond to students, use fewer directives, encourage student initiative, and focus less on seeking student compliance (Reeve et al., 1999). In contrast, TCs with controlling motivational orientations demonstrate lower levels of self-determined motivation to teach, are less socially engaged with students, and more controlling in their interactions with students (Reeve et al. 1999).

TCs' motivational orientations are malleable. When TCs with controlling motivational orientations are provided with a rationale explaining the importance of supporting students' self-determined motivation and given specific strategies to do so, they significantly increase their autonomy-supportive instructional behaviour (Reeve et al., 2018). Therefore, it appears TCs' motivational orientations act in tandem with contextual features to shape their teaching practices.

Extending Reeve et al's (1999) research to authentic settings, Evelein et al. (2008) found that TCs' perceived relatedness is associated with student characteristics, while their needs for autonomy and competence is influenced most by: (a) TCs' teaching experiences during single lessons, (b) the time lessons are taught during TCs' practicums (at the beginning, middle, or end of their practicum; measured at six time points throughout the practicums), and (c) TCs' personal characteristics (variance in responses by individual TCs). These findings suggest TCs' experiences of need fulfillment are fluid-they change in response to TCs' experiences teaching individual lessons and throughout their TEPs.

In 2016, Korthangen and Evelein investigated the relationship between Dutch TCs' $(\mathrm{N}=36)$ SD need fulfilment and their classroom interactions. TCs' perceptions of their SD needs were initially measured with the Basic Psychological Needs Questionnaire (Sheldon et al., 2001). Then, over a 14 week period, TCs self-rated their classroom interactions on a questionnaire entitled, Questionnaire on Teacher Interaction (Reis et al., 2000). This measure provided data about TCs' "proximity" behaviours, or behaviours that indicate a balance between "control and "submission" in interactions between TCs and students within their practicum setting. A balance in these behaviours indicates TCs are interacting with students in an autonomously supportive manner (e.g. teacher leadership with space for student voice, flexible expectations, and structures for support). Results from this study indicate a strong correlation between TCs "leadership behavior" (autonomy supportive practices with structure) and their perceptions of competence $(\mathrm{r}=0.93, p=0.001)$. Therefore, it appears in addition to competency supports for specific teaching practices (e.g., SRLPPs), TCs need opportunities to learn about the impact of their interaction styles with students, specially ways in which they can develop a balance between their provision of leadership and the creation of opportunities for students to function autonomously. 


\section{SD needs and TCs' uptake of SRLPPs}

TCs' motivational orientations and their valuing of instructional practices are open to change if contextual conditions support their feelings of competence (e.g., informational support, scaffolded instruction, supportive relationships, autonomy to engage in learning experiences in a way that fits with their prior knowledge and [life] goals). Through an SDT lens, the provision of these supports underlies TCs' internal motivation to engage in tasks. Through active engagement, TCs are able to gather information and make judgments about the value of teaching practices for themselves.

Research from SRL theory suggests TCs may be more likely to value and use SRLPPs if they have opportunities to: (a) receive informational support, (b) discuss their practice with others, (c) think about and reflect upon and evaluate their practice, and (d) receive support to continually interpret and adjust both theory and research to suit their professional practice (Butler, 1998). Common among SDT and SRL theory, is the need for TCs to be provided with supports for autonomy (to interpret and restructure beliefs and practice in a way that is personally meaningful), relatedness (to have their beliefs challenged by others, to discuss new practice with others), and competence (informational support).

- SRL and SDT create a framework for facilitating TCs' promotion of practices that facilitate students' development of generalized learning competences. SRL contributes a clear description of the underlying processes for developing competencies (e.g., metacognition, motivation, strategic action) and tangible classroom practices that support the development of these processes. In turn, SDT offers explicit, wellfounded descriptions of how TCs' motivation (e.g. support for autonomy, competence and relatedness) can be supported as they engage in the development of these new and often complex teaching practices. Figure 1 below provides an overview of how autonomy supportive environments foster TCs' development of SRLPPs and thereby students' development of generalized learning competencies.

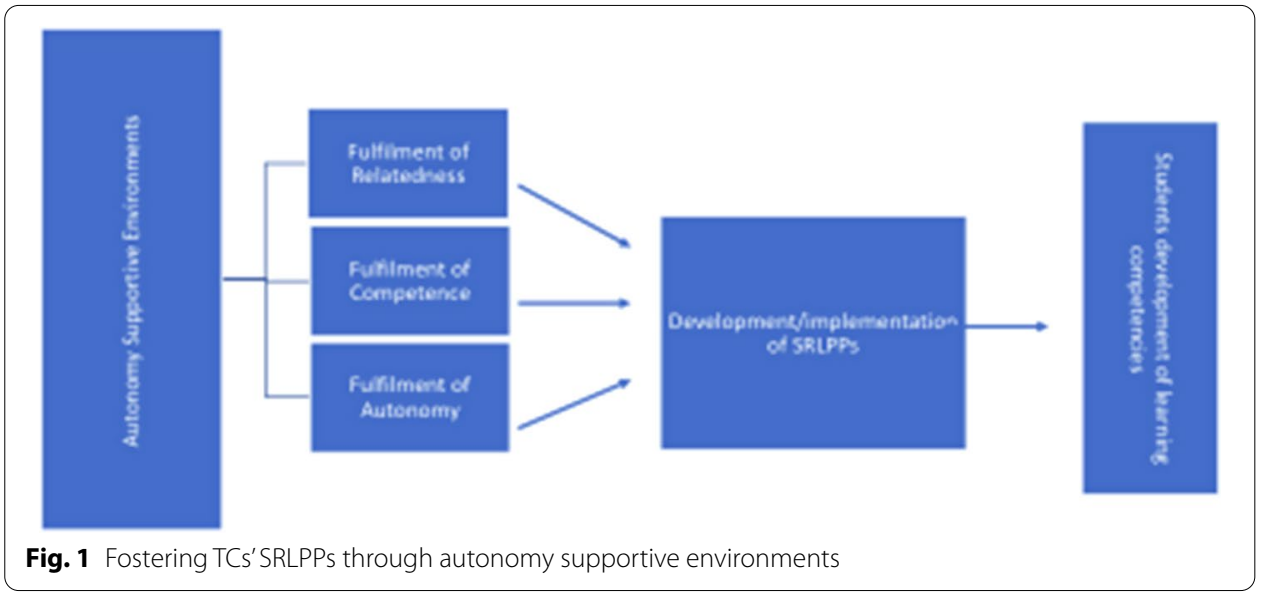




\section{Moving forward}

Given the impact of autonomy supportive contexts on TCs' uptake of SRLPPs, it is important to continue to identify conditions that shape TCs' motivation, particularly during their practicum experiences. To this end, Evelein et al., (2008) and Korthangen and Evelein (2016), call for future studies that: (a) clarify the connections between TCs' perceptions of SD need fulfillment and their practicum teaching experiences, (b) identify and examine contextual features that serve to support or hinder TCs' experiences of need fulfillment throughout their practicum, (c) investigate how to support TCs throughout their TEPs, and (d) attend to TCs' motivation and learning over a prolonged period of time. Likewise, Lombaerts et al. (2009) and Steinbach and Stoeger (2016) cite a need for in-depth studies that examine teachers' personal characteristics (e.g., level of experience, educational experiences, SRL experiences, "eagerness to innovate") and connections between contextual supports and barriers and their availability for teachers' development and implementation of SRLPPs. Finally, further research is needed to investigate TCs' understanding, use and timely application of SRLPPs in authentic classroom settings using varied methods of data collection. With the exceptions of Brenner, 2020; Perry $(1998,2013)$, Butler and Schnellert (2012), and Reeve et al., (2004) few programs of research exist that investigate TCs' and teachers' implementation of SRLPPs and/or support for their' self-determined motivation in actual classroom settings. While Perry (1998, 2013), Butler and Schnellert (2012), Brenner (2020) have used multiple methods to gather information about TCs'/teachers' promotion of SRL, the majority of studies rely entirely on selfreport questionnaires to learn about teachers' practices. Therefore, moving forward a need exists to investigate links between TCs' uptake of SRLPPs through longitudinal research, that encompasses multiple research methods within authentic settings.

Acknowledgements

Not applicable.

Authors' contributions

I, Charlotte Brenner researched and wrote this independently. I am the sole author. The author read and approved the final manuscript.

Funding

Not applicable

Availability of data

Data is available from the author upon request.

\section{Declarations}

Competing interests

The author declares that he has no competing interests.

Author details

${ }^{1}$ University of British Columbia, Scarfe Building, Main Mall, Vancouver, BC V6T 1Z4, Canada. ${ }^{2} 417$ - 1664 56th Street, Delta, BC V4L 2M6, Canada.

Received: 1 September 2021 Accepted: 22 December 2021

Published online: 06 January 2022

References

Baard, P. P. (1994). A motivational model for consulting with not-for-profit organizations: A study of church growth and participation. Consulting Psychology Journal, 46, 9-31. 
Baard, P. P., Deci, E. L., \& Ryan, R. M. (2004). Intrinsic need satisfaction: A motivational basis of performance and well-being in two work settings. Journal of Applied Social Psychology, 34(10), 2045-2068.

Black, A. E., \& Deci, E. L. (2000). The effects of instructors' autonomy support and students' autonomous motivation on learning organic chemistry: A self-determination theory perspective. Science Education, 84(6), 740-756.

Brenner, C.A. (2020). Open collections. Doctoral dissertation, University of British Columbia.

Brown, A. L., \& Campione, J. C. (1994). Guided discovery in a community of learners. In K. McGilly (Ed.), Classroom lessons: Integrating cognitive theory and classroom practice (pp. 229-270). The MIT Press.

Butler, L. D., \& Cartier S. C. (2004). Multiple complementary methods for understanding self-regulated learning as situated in context. Paper presented at annual conference of American Education Research Association, Montreal, Quebec. http://citeseerx.ist.psu.edu/viewdoc/summary;jsessionid=CC3FC213FE6756F4B131B74FE1F439E5\%?doi=10.1.1. 700.868.

Butler, D. L. (1998). The strategic content learning approach to promoting self-regulated learning: A report of three studies. Journal of Educational Psychology, 90(4), 682-697.

Butler, D. L., \& Schnellert, L. (2012). Collaborative inquiry in teacher professional development. Teaching and Teacher Education, 28(8), 1206-1220. https://doi.org/10.1016/j.tate.2012.07.009.

Butler, D. L., Schnellert, L., \& MacNeil, K. (2014). Collaborative inquiry and distributed agency in educational change: A case study of a multi-level community of inquiry. Journal of Educational Change, 16(1), 1-26.

Butler, L. D., \& Cartier, S. C. (2018). Case studies as a methodological framework for studying and assessing self-regulated learning. In D. Schunk \& J. Greene (Eds.), Handbook of self-regulated learning and performance (2nd ed., pp. 352-369). Routledge.

Carson, R. L., \& Chase, M. A. (2009). An examination of physical education teacher motivation from self-determination theoretical framework. Physical Education and Sport Pedagogy, 14(4), 335-353.

Cheon, S. H., Reeve, J., Yu, T. H., \& Jang, H. R. (2014). The teacher benefits from giving autonomy support during physical education instruction. Journal of Sports and Exercise Psychology, 36, 331-346.

Deci, E. L., \& Ryan, R. M. (1991). A motivational approach to self: Integration in personality. In R. A. Dienstbeir (Ed.), Current theory and research in motivation, 38. Nebraska Symposium on Motivation 1990: Perspectives on Motivation (pp. 237-288). University of Nebraska Press.

Deci, E. L., \& Ryan, R. M. (2014). Autonomy and need satisfaction in close relationships: Relationships motivation theory. In N. Weinstein (Ed.), Human motivation and interpersonal relationships: Theory, research, and application (pp. 53-76). Springer.

Deci, E. L., Eghrari, H., Patrick, B. C., \& Leone, D. R. (1994). Facilitating internalization: The self-determination theory perspective. Journal of Personality, 62, 119-142.

Deci, E. L., Nezlek, J., \& Sheinman, L. (1981). Characteristics of the rewarder and intrinsic motivation of the rewardee. Journal of Personality and Social Psychology, 40, 1-10.

Deci, E. L., \& Ryan, R. M. (1985). The general causality orientations scale: Self-determination in personality. Journal of Research in Personality, 19, 109-134.

Deci, E. L., \& Ryan, R. M. (2000). Self-determination theory and the facilitation of intrinsic motivation. American Psychologist, 55, 68-78.

Deci, E. L., \& Ryan, R. M. (Eds.). (2002). Handbook of self-determination research. University of Rochester Press.

Deci, E. L., \& Ryan, R. M. (2008). Self-determination theory: A macrotheory of human motivation, development, and health. Canadian Psychology/psychologie Canadienne, 49(3), 182-185.

Deci, E. L., \& Ryan, R. M. (2012). Motivation, personality, and development within embedded social contexts: An overview of self-determination theory. In R. M. Ryan (Ed.), The Oxford handbook of human motivation (pp. 85-107). Oxford University Press.

Elliot, A. J., McGregor, H. A., \& Trash, T. M. (2002). The need for competence. In E. L. Deci \& R. M. Ryan (Eds.), Handbook of self-determination research (pp. 361-387). University of Rochester Press.

Evelein, F., Korthagen, F. A. J., \& Brekelmans, M. (2008). Fulfilment of the basic psychological needs of student teachers during their first teaching experiences. Teaching and Teacher Education, 24, 1137-1148.

Fuller, F., \& Bown, O. (1975). Becoming a teacher. In: K. Ryan (Ed.), Teacher education, 74th yearbook of the national society for the study of education: Part 2 (pp. 25-52).

Gagné, M., \& Deci, E. L. (2005). Self-determination theory and work motivation. Journal of Organizational Behavior, 26, $331-362$.

Hadwin, A., Jarvela, S., \& Miller, M. (2018). Self-regulation, co-regulation and shared regulation in collaborative learning environments. In D.H. Schunk \& J. A. Greene (Eds.) Educational psychology handbook series. Handbook of self-regulation, learning and performance (PP. 83-106). Routledge: Taylor and Francis Group.

Howard, J. L., Gagne, M., \& Bureau, J. S. (2017). Testing a continuum structure of self determined motivation: A metaanalysis. Psychological Bulletin, 143(12), 1346.

Hutchinson, L. (2013). Young children's engagement in self-regulation at school. Unpublished doctoral dissertation. University of British Columbia, Vancouver, Canada.

Jang, H. (2009). Can self-determination theory explain what underlies the productive, satisfying learning experiences of collectivistically oriented Korean students. Journal of Educational Psychology, 3, 664-661.

Jang, H., Reeve, J., \& Deci, E. L. (2010). Engaging students in learning activities: It is not autonomy support or structure but autonomy support and structure. Journal of Educational Psychology, 102(3), 588-600.

Jang, H., Reeve, J., \& Halusic, M. (2016). A new autonomy-supportive way of teaching that increases conceptual learning: Teaching in students' preferred ways. Journal of Experimental Education, 84(4), 686-701.

Jesus, S. N., \& Lens, W. (2005). An integrated model for the study of teacher motivation. Applied Psychology: An International Review, 54, 119-134.

Klassen, R. M., Perry, N. E., \& Frenzel, A. C. (2012). Teachers' relatedness with students: An underemphasized component of teachers' basic psychological needs. Journal of Educational Psychology, 104, 150-165.

Korthangen, F. A. J., \& Evelein, F. G. (2016). Relations between student teachers' basic needs fulfillment and their teaching behavior. Teaching and Teacher Education, 60, 234-244. 
Lam, S. F., Cheng, R. W., \& Choy, H. C. (2010). School support and teacher motivation to implement project-based learning. Learning and Instruction, 20(6), 487-497.

Lee, W., \& Reeve, J. (2017). Identifying the neural substrates of intrinsic motivation during task performance. Cognitive Affective, and Behavioral Neuroscience, 17(5), 939-953.

Levesque, C., Zuehlke, A. N., Stanek, L. R., \& Ryan, R. M. (2004). Autonomy and competence in German and American university students: A comparative study based on self-determination theory. Journal of Educational Psychology, 96, 68-85.

Liu, W., Wang, C. K., Reeve, J., Kee, Y., \& Chain, L. (2019). What determines teachers' use of motivational strategies in classrooms? A self-determination theory perspective. Journal of Education, 26(7), 1404-1415.

Lombaerts, K., Engels, N., \& van Braak, J. (2009). Determinants of teachers' recognitions of self-regulated learning practices in elementary education. The Journal of Educational Research, 102(3), 163-173.

Marshik, T. T. (2010). Teachers' and students' psychological needs satisfaction as predictors of students' academic achievement. Unpublished doctoral dissertation. University of Florida, Florida.

McCaslin, M. (2009). Co-regulation of student motivation and emergent identity. Educational Psychologist, 44(2), 137-146.

McClelland, M., \& Wanless, S. (2012). Growing up with assets and risks: The importance of self-regulation for academic achievement. Research in Human Development, 9, 9278-9297.

Niemiec, C. P., \& Ryan, R. M. (2009). Autonomy, competence, and relatedness in the classroom: Applying self-determination theory to educational practice. Theory and Research in Education, 7(2), 133-144.

Organisation for Economic Development and Cooperation. (2013). Pisa 2012 results: What makes schools successful? Resources, policies and practices (Vol. 4). OECD Publishing.

Pelletier, L. G., Seguin-Levesque, C., \& Legault, L. (2002). Pressure from above and pressure from below as determinants of teachers' motivational and teaching behaviours. Journal of Educational Psychology, 94(1), 186-196.

Pelletier, L. G., \& Sharp, E. C. (2009). Administrative pressures and teachers' interpersonal behaviour in the classroom. Theory and Research in Education, 7(2), 174-183.

Perry, N. E. (2013). Classroom processes that support self-regulation in young children [Monograph]. British Journal of Educational Psychology. In Monograph series II: Psychological aspects of education-current trends (Vol. 10, pp. 45-68).

Perry, N. E. (1998). Young children's self-regulated learning and the contexts that support it. Journal of Educational Psychology, 90,715-729.

Perry, N. E., Collie, R \& Brenner, C. A. (2012). Paper presented at the biennial meeting of the SIG 16, Metacognition, of the European Association for Research on Learning and Instruction, Milan.

Perry, N. E., Mazabel, S., Dantzer, B., \& Winnie, P. (2018). Supporting self-regulation and self-determination in the context of music education. In G. A. D. Liem \& D. M. McInerney (Eds.), Big theories revisited 2: A volume of research on sociocultural influences on motivation and learning. Information Age.

Perry, N. E., Phillips, L., \& Hutchinson, L. (2006). Mentoring student teachers to support self-regulated learning. The Elementary School Journal, 106(3), 237-254.

Perry, N. E., \& Rahim, A. (2011). Studying self-regulated learning in classrooms. In B. J. Zimmerman \& D. H. Schunk (Eds.), Handbook of self-regulation of learning and performance (pp. 122-136). Routledge/Taylor \& Francis Group.

Perry, N. E., VandeKamp, K. O., Mercer, L. K., \& Nordby, C. J. (2002). Investigating teacher student interactions that foster self-regulated learning. Educational Psychologist, 37, 5-15.

Perry, N. E., Yee, N., Mazabel, S., Lisaingo, S., \& Maatta, E. (2017). Using self-regulated learning for creating inclusive classrooms for ethnically and linguistically diverse in Canada. In N. J. Cabrera \& B. Leyendecker (Eds). Handbook of positive development of minority and youth (pp. 361-385). Switzerland: Springer.

Podell, D. M., \& Soodak, L. C. (1993). Teacher efficacy and bias in special education referrals. Journal of Educational Research, 86(4), 247-253.

Reeve, J. (2002). Self-determination theory applied to educational settings. In E. L. Deci \& R. M. Ryan (Eds.), Handbook of self-determination research (pp. 183-205). University of Rochester Press.

Reeve, J. (2009). Why teachers adopt a controlling motivation style toward students and how they can become more autonomy supportive. Educational Psychologist, 44, 159-175.

Reeve, J. (2015). Autonomy-supportive teaching:What it is, how to do it. In J. C. K. Wang, W. C. Liu, \& R. M. Ryan's (Eds.), Motivation in educational research: Translating theory into classroom practice (pp. 129-153). Springer.

Reeve, J., \& Assor, A. (2011). Do social institutions necessarily suppress individuals' need for autonomy: The possibility of schools as autonomy-promoting contexts across the globe. Cross-Cultural Advancements in Positive Psychology, 1(2), $111-132$.

Reeve, J., Bolt, E., \& Cai, Y. (1999). Autonomy-supportive teachers: How they teach and motivate students. Journal of Educational Psychology, 91(3), 537-548.

Reeve, J., \& Jang, H. (2006). What teachers say and do to support students' autonomy during a learning activity. Journal of Educational Psychology, 98, 209-218.

Reeve, J., Jang, H., Carrell, D., Jeon, S., \& Barch, J. (2004). Enhancing students' engagement by increasing teachers' autonomy support. Motivation and Emotion, 28(2), 147-169.

Reeve, J., Nix, G., \& Hamm, D. (2003). Testing models of the experience of self-determination in intrinsic motivation and the conundrum of choice. Journal of Educational Psychology, 95, 375-392.

Reeve, J., Ryan, R. M., \& Deci, E. L. (2018). Sociocultural influences on student motivation as viewed through the lens of self-determination theory. In G. A. D. Liem \& D. M. McInernery (Eds.), Big theories revisited (pp. 15-40). Information Age.

Reis, H. T., Sheldon, K. M., Gable, S. L., Roscoe, J., \& Ryan, R. M. (2000). Daily well-being: The role of autonomy, competence, and relatedness. Personality and Social Psychology Bulletin, 26(4), 419-435.

Roth, G., Assor, A., Kanat-Maymon, Y., \& Kaplan, H. (2007). Autonomous motivation for teaching: How self-determined teaching may lead to self-determined learning. Journal of Educational Psychology, 99(4), 744-761.

Ryan, R. M., \& Brown, K. W. (2005). Legislating competence: High-stakes testing policies and their relations with psychological theories and research. In A. J. Elliot \& C. S. Dweck (Eds.), Handbook of competence and motivation (pp. 354-372) 
Ryan, R. M. (1995). Psychological needs and the facilitation of integrative processes. Journal of Personality, 63, 397-427. Ryan, R. M., \& Deci, E. L. (2002). Overview of self-deamination theory: An organismic-dialectical perspective. In E. L. Deci \& R. M. Ryan (Eds.), Handbook of self-determination research (pp. 3-33). University of Rochester Press.

Ryan, R. M., \& Deci, E. L. (2017). Self-determination theory: Basic psychological needs in motivation, development, and wellness. Guilford.

Ryan, R. M., \& Weinstein, N. (2009). Undermining quality teaching and learning: A self determination theory perspective on high-stakes testing. Theory and Research in Education, 7(2), 224-233.

Schellenbach-Zell, J., \& Cornelia, G. (2010). Teacher motivation for participating in school innovations-supporting factors. Journal for Educational Research Online, 2, 34-54.

Sheldon, K. M., Elliot, A. J., Kim, Y., \& Kasser, T. (2001). What is satisfying about satisfying events? Testing 10 candidate psychological needs. Journal of Personality and Social Psychology, 80, 325-339.

Sheldon, K. M., \& Krieger, L. S. (2007). Understanding the negative effects of legal education on law students: A longitudinal test of self-determination theory. Personality and Social Psychology Bulletin, 33, 883-897.

Sheldon, K. M., \& Ryan, R. M. (2011). Positive psychology and self-determination theory: A natural interface. In V. I. Chirkov, R. M. Ryan, \& K. M. Sheldon (Eds.), Human autonomy in cross-cultural contexts (pp. 33-44). Springer.

Skinner, E., \& Edge, K. (2002). Self-determination, coping, and development. In E. L. Deci \& R. M. Ryan (Eds.), Handbook of self-determination research (pp. 297-337). University of Rochester Press.

Steinbach, J., \& Stoeger, H. (2016). How primary school teachers' attitudes towards self-regulated learning (SRL) influences instructional behavior and training implementation in classrooms. Teaching and Teacher Education, 60, 256-269.

Stoeger, H., Fleischmann, S., \& Obergriesser, S. (2015). Self-regulated learning (SRL) and the gifted learner in primary school: The theoretical basis and empirical findings on a research program dedicated to ensuring that all students learn to regulate their own learning. Asia Pacific Education Review, 16(2), 257-267.

Taylor, I. M., Ntoumanis, N., \& Standage, M. (2008). A self-determination theory approach to understanding the antecedents of teachers' motivational strategies in physical education. Journal of Sport and Exercise Psychology, 30, 75-94.

Tschannen-Moran, M., \& Woolfolk-Hoy, A. (2007). The differential antecedents of self-efficacy beliefs of novice and experienced teachers. Teaching and Teacher Education, 23, 944-956.

Vallerand, R. J., \& Ratelle, C. F. (2002). Intrinsic and extrinsic motivation: A hierarchical model. Handbook of Self-Determination Research, 128, 37-63.

Vansteenkiste, M., Lens, W., \& Deci, E. L. (2006). Intrinsic versus extrinsic goal contents in self-determination theory: Another look at the quality of academic motivation. Educational Psychologist, 41, 19-31.

Vygotsky, L. S. (1978). Mind in society. Harvard University Press.

Whitaker, S. (2000). Mentoring beginning special education teachers and the relationship to attrition. Exceptional Children $66,546-566$.

White, R. W. (1959). Motivation reconsidered: The concept of competence. Psychological Review, 66, 297-333.

Williams, G. C., \& Deci, E. L. (1996). Internalization of biopsychosocial values by medical students: A test of self-determination theory. Journal of Personality and Social Psychology, 70, 767-779.

Winne, P. H., \& Hadwin, A. F. (1998). Studying as self-regulated learning. In D. J. Hacker, J. Dunlosky, \& A. C. Greaesser (Eds.), The educational psychology series. Metacognition in educational theory and practices (pp. 277-304). Lawrence Erlbaum Associates Publishers.

Winne, P. H., \& Perry, N. E. (2000). Measuring self-regulated learning. In M. Boekaerts, P. R. Pintrich, \& M. Ziedner (Eds.), Handbook of self-regulation (pp. 531-566). Academic Press.

Woolfolk, A. E., Rosoff, B., \& Hoy, W. K. (1990). Teachers' sense of efficacy and their beliefs about managing students. Teaching and Teacher Education, 6, 137-148.

Wong, B. Y. L., Harris, K. R., Graham, S., \& Butler, D. L. (2003). Cognitive strategies instruction research in learning disabilities. In H. Lee Swanson, K. R. Harris, \& S. Graham (Eds.), Handbook of learning disabilities (pp. 383-402). New York: Guilford Press.

Zimmerman, B. J. (1990). Self-regulated learning and academic achievement: An overview. Educational Psychologist, 25(1), 3-17.

Zimmerman, B. J. (2000). Attainment of self-regulation: A social cognitive perspective. In M. Boekaerts, P. R. Pintrich, \& M. Zeidner (Eds.), Handbook of self-regulation (pp. 13-39). Academic Press.

Zimmerman, B. J. (2002). Becoming a self-regulated learner: An overview. Theory into Practices, 41(2), 64-70.

Zimmerman, B. J. (2008). Investigating self-regulation and motivation: Historical background, methodological developments, and future prospects. American Educational Research Journal, 45, 166-183.

Zimmerman, B. J., \& Schunk, D. H. (2011). Self-regulated learning and performance: An introduction and an overview. In B. Zimmerman \& D. Schunk (Eds.), Handbook of self regulation of learning and performance (pp. 1-12). Routledge.

\section{Publisher's Note}

Springer Nature remains neutral with regard to jurisdictional claims in published maps and institutional affiliations. 